\title{
A comparative analysis of entrepreneurial intention and migration attitudes of students in $\mathrm{Vi}$ - etnam and Poland
}

\section{Thanh Le Trunga ${ }^{\mathrm{a}}$, Hau Doan Xuan ${ }^{\mathrm{a}}$, Huyen Nguyen Ngoc ${ }^{\mathrm{a}}$, Doanh Duong Cong ${ }^{\mathrm{a}}$ and Linh Ngu- yen Thi Phuonga}

${ }^{a}$ National Economics University, Vietnam

\begin{tabular}{|c|c|}
\hline CHRON I C L E & A B S T R A C T \\
\hline $\begin{array}{l}\text { Article history: } \\
\text { Received: July } 52019 \\
\text { Received in revised format: July } \\
102019 \\
\text { Accepted: August } 18,2019 \\
\text { Available online: } \\
\text { August } 18,2019 \\
\text { Keywords: } \\
\text { Entrepreneurial intention } \\
\text { Migration attitudes } \\
\text { Students }\end{array}$ & $\begin{array}{l}\text { The concept of entrepreneurship has become popular in different countries such as Vietnam and Poland. How- } \\
\text { ever, there are few comparative researches on entrepreneurial intention and migration attitudes among students } \\
\text { in two countries. The purpose of this study is to show a comparative analysis of some issues related to entre- } \\
\text { preneurial intention and migration attitudes such as willingness to take the risks, knowledge about the market, } \\
\text { competitors, financial resources, factors effecting on entrepreneurial intention, circumstance and the purpose of } \\
\text { going abroad among students in Vietnam and Poland. The study employs quantitative analyses by utilizing } \\
\text { some tools of descriptive statistics and Mann Whitney U-Test through SPSS } 20.0 \text { to show the differences of } \\
\text { factors affecting on intention to start up a business and migration attitudes between Vietnamese and Polish } \\
\text { students. The research results show that although the demographic layout of students in two countries was rather } \\
\text { similar, there were some differences in } 12 \text { out of } 17 \text { factors influencing on entrepreneurial intention of Viet- } \\
\text { namese and Polish students. In terms of migration attitudes, almost all Vietnamese and Polish students were } \\
\text { interested in going abroad to find a job and only minor proportion of them planned to run a business abroad. }\end{array}$ \\
\hline
\end{tabular}

C 2020 by the authors; licensee Growing Science, Canada

\section{Introduction}

There is a growing awareness on the concepts of entrepreneurship and entrepreneurs in the world, especially in the context of migration decisions nowadays. Entrepreneurship activity not only acts as a catalyst for national economic development but it also creates a number of new jobs for the society. Therefore, there is a need to determine different factors associated with entrepreneurial intention and the assessment of willingness to take risks, knowledge of students about finances, market in order to foster youths starting their own businesses and creating new venture activities. Besides, the problem of students who declare their willingness to develop their professional future outside the borders of the homeland also should be concerned. Moreover, these determinations are also essential for authorities and governments in terms of promulgating suitable law and policy to create effective entrepreneurial ecosystem.

Since "Đổi Mới” (Renovation process) in 1986, The Vietnamese economy has transformed from planned to market-oriented economy. By pursuing the new policies, Vietnam Government encouraged internal restructuring. According to the Doing Business 2017 Report of the World Bank, Vietnam ranks 60 $0^{\text {th }}$ among 138 countries in the Global Competitive Report 2017. Vietnam attracted more foreign direct investment (FDI) than China in 2016 and surpassed Malaysia and Thailand in the Greenfield FDI Performance Index, leading in the region (Doing Business in Vietnam, 2017). In addition, in 2007, FDI in Vietnam reached the highest number over the 10-year period, amounting to USD 35 billion. By the end of November 2017, the figure for FDI projects reached 24,580 registrations, accounting for USD 317 billion. While around $60 \%$ of the funds were allocated to the processing and manufacturing industries, $16.6 \%$ of FDI projects poured into real estate and only $6.6 \%$ was spent on the utility supply sector. In fact, South Korea is still seen as the top investing nation with the registered capital of USD 57.5 billion, accounting for $29 \%$ of more than 100 nations and territories, followed by Japan (11\%) and Singapore (10\%)

* Corresponding author.

E-mail address: doanhdoanh.qtkd.neu@gmail.com (D. Duong Cong) 
(VNEXPRESS, 2017). The population of Vietnam is over 92 million people, with the median age of 30 , ranked as the $14^{\text {th }}$ most populous nation in the world. As a result, Vietnam attracts many investors because of its potential customers and employees. In terms of gross domestic product (GDP) growth, GDP in 2015 was $6.7 \%$, however, it dropped to only $6.2 \%$ in 2016 before an impressive recovery in 2017, when it reached 6.8\%. Consequently, Vietnam's GDP growth has averaged approximately $7 \%$ over the last 20 years. Consequently, the recognition of the role of entrepreneurship is growing among government, society and researchers as well. According to the General Statistics Office (GSO, 2017), there are 561,064 active enterprises in Vietnam, increased by $11.1 \%$ in comparison with previous year. 126,859 new enterprises were established in 2017 , increased by $15 \%$ - the highest level of enterprises established, the average capital of each firm is estimated at 448,800 USD. Keeping pace with the high rate of economic growth of Vietnam, private sectors increased significantly and contributed nearly $40 \%$ to GDP and the private firms is projected to contribute $50 \%$ to GDP by 2020 .

Analogously to Vietnam, market economy in Poland was established only after 1989. As a consequence of the imposition of the Communism ideology after World War II, with the control of economy and social life modeled upon the Soviet Union, entrepreneurship issue was not a concern. Poland and many other Central European countries functioned as a system of centrally planned economies where the importance of profit-oriented sector was minimized as much as possible. As a consequence of political and economic principles, private and profit-seeking entities were almost entirely rejected. Entrepreneurship was not as common in the centrally planned system as it was the case in other market economies in Europe. As reported by UNCTAD 2017 World Investment Report, despite FDI, Poland is among the most attractive nations in Europe. FDI inflows into Poland showed a reduction from USD 13.5 billion in 2015 to only USD 11.4 billion in 2016 . This trend reflects the global economic crisis and the economic slowdown effectuated by the Eurozone crisis of 2012-2013. According to World Bank (2017), GDP growth reached nearly $4.0 \%$ in 2017 , compared with only $2.7 \%$ in 2016 . However, as a result of the impact of lower economic activity in Europe and labor shortages on the domestic market, the economy in Poland is predicted to be slowing down in 2018. According to Global Entrepreneurship Monitor (GEM) in Poland (2017), there is an increase in the percentage of individuals finding opportunities to start up their own business in 2016. Noticeably, it is the first time in GEM research, Poland reached a result better than the average level in EU. However, the fear of failure in business was still seen as the largest obstacle in developing entrepreneurship in Poland since $48 \%$ of Polish although recognize the business opportunities in the environment, not decide to start up their own business because of fear of failure, in comparison with only $41 \%$ among the EU residents

Even though there are lots of studies related to entrepreneurship field, most of these studies were conducted in developed countries, where entrepreneurial ecosystem is very developed and business environment is to create the most favorable conditions for entrepreneur. A few researches about entrepreneurial intention, especially in the migration context, have been conducted in Vietnam and Poland-transitional economies and developing countries. As a result, there are a number of research gaps in this field that need to be fulfilled, and authors would like to give additional understanding of student's intention to become entrepreneur and their willingness to emigrate for developing their professional future in their own companies founded abroad. More specially, the objective of this research is to investigate and compare the entrepreneurial intention and migration attitudes among Vietnamese and Polish students. Also, the study provides important sightseeing for policy makers, educational reforming in entrepreneurial training and fostering youths starting their own businesses. The authors also collected further data by sending out similar number of surveys to students in various universities in Poland. 663 responses received from Vietnamese students and 710 responses from Polish students were enough for the purposes of this study. Certain descriptive statistics, Mann Whitney U-Test were also used to investigate the intention to start up a business and migration attitudes of students in Vietnam and Poland. The structure of the paper is organized in the following manner: first, definitions and literature review related to entrepreneurship, entrepreneurial intention, migration attitudes are given. Second, country profiles and overview of Polish and Vietnamese entrepreneurship are stated. Third, description of the methodology, research questions are provided. Fourth, the presentation of research result and its analysis followed by the comparison of the entrepreneurial intention and migration attitudes of Vietnamese and Polish students are presented and finally, the representation of the conclusion and recommendations for further research are given.

\section{Literature review}

\subsection{Entrepreneurship}

Entrepreneurship research is still seen as the developing field within the area of a management science. Moreover, its own method and theories are also need to be developed (Kot et al., 2016, p. 208; Churchill \& Bygrave, 1989, p. 8). In the 18 ${ }^{\text {th }}$ century, Cantillon, a French economist, was one of the first researchers who proposed the definitions of entrepreneur and proved the relationship of an individual's entrepreneurial behavior and specific economic system. He stated that demand and supply on the market were diverged, that led to the possibility of buying something at a lower price and selling it at a higher price. He also noticed that entrepreneur was an individual capable of such opportunities to increase profits. Interestingly, Cantillon gave a definition of entrepreneurship and stated that entrepreneurship is the ability of recognizing the opportunities emerging on the market and grasping them in spite of unexpected changes of the market. The difference between potential and actual products or services on the market allows entrepreneurs to earn profits and encourages them to take actions effectively in the future (Kopycińska et al., 2006, p. 24). There are many definitions for entrepreneurship developed over the few recent decades. Schumpeter (1960) explained that entrepreneurs are people who create new products or services in new or existing market and entrepreneurship becomes one of the most important factors in countries' economic growth (Schumpeter, 
1960, p.12; De Bruin et al., 2006, p. 686). “The environment itself creates entrepreneurship” (Bernat et al., 2016, p. 271), the reason is that operating organizations is necessary not only for reacting quickly to unanticipated changes, but also for adapting to unpredicted outcomes (Timmons, 1990). Kirzner (1985) defined that entrepreneur is a person who might optimize information in such a way in order to discover the new and improved business opportunities (Korpysa, 2012). Talpas (2014, p.198) considered entrepreneurship as a process who could be recognized throughout business activities by showing effective leadership within uncertain market, risks and competitive conditions, while Zimmerer and Scarborough (1996, p.19) claimed that entrepreneurs can also be known as the owners who, with skillful manner, are able to associate various factors of production, transform a smaller economic resources into a bigger platform effectively. Also, Entrepreneurship is the process of creating and building new venture and new business organization (Shane \& Venkataraman, 2000), that not only provides goods and services, creates job opportunities but also contributes to the development of economy and the national income. In summary, character words, such as willingness to take risks, innovativeness, opportunism, new products, new processes, and creating a new business venture, are concluded in combined definitions (Bird \& Brush, 2002, p. 41). Generally, entrepreneurship is a new business creation by a person alone or cooperating with others.

In addition, entrepreneurship is connected with economic activities (Kot et al., 2016, p. 208). In fact, many governments and scientists take consideration into the development of Small and Medium Enterprises (SMEs), which are perceived as the sustainable path to develop national economies (Sivvam, 2012, p.13; Ambrish, 2014, p.225). Entrepreneurship can be also defined as a conscious action of individuals, which relies on various conditions including economic activities, technologies, culture, policy and social and political problems. However, willingness to take risk plays the important part of achieving successes in business. Thus, entrepreneurs are responsible to act in a manner that paves the ways for economic activities and generating wealth by increasing income, developing skills and creating jobs (Gaweł, 2010, p. 60).

\subsection{Entrepreneurial intention}

Individual entrepreneurial intention can be most appropriately and practically defined as the intention of a person to start up a new own business venture and intentionally plan to do so in the future. However, this time can be imminent and indeterminate, or might never be achieved in the future (Thompson, 2009, p.676). There are many reasons such as personal circumstances, social and politic issues and business environment, which might become either big obstacles or motivated factors to transform this intent becoming a reality. Thus, entrepreneurial intention is perceived as an essential and fundamental condition to be a nascent entrepreneur. Whereas entrepreneurship is determined as the emergent process of an organization (Gartner et al., 1992), an individual's intention to pursue an entrepreneurial career is crucial to this process (Lee et al., 2011, p.126). Moreover, entrepreneurial intention is considered the first step in a series of actions to found an organization (Bird, 1988), yet Fishbein and Ajzen (1975) argued that intentions toward a behavior can be seen as important indicators of that behavior. In other words, intentions are still seen as the best predictor of individual behavior (Krueger, 2008). According to Ajzen (1991), who introduced Theory of Planned Behavior, intentions are determined by social/subjective norms and perceived behavioral control. Social norms are considered individual's perception of his or her behavior that is consistent with significant thoughts of other, while perceives behavior control is the range of the target behavior within the ability of a decision maker (Esfandiar et al., 2017). Do and Dadvari (2016) also defined entrepreneurial intention as an attentive state of mind that reflects personal experience, awareness and interest toward planned entrepreneurial activity. Since the decision to be an entrepreneur is voluntary and conscious (Krueger et al., 2000). Entrepreneurship is necessary to succeed in the long-term and reflects the economic growth prospects of a country as well. Paul and Shrivatava (2016) have shown a comparative investigation of entrepreneurial intention, country culture and proactive behavior among young managers in India (developing country) and Japan (developed country) based on statistical analysis. The study indicated that the entrepreneurial intentions of young managers from developing countries was not always stronger than that of those from developed countries although in behalf of the entrepreneurial level, developing countries such as India often stand behind developed countries, like Japan. Consequently, it is essential to develop entrepreneurial skills and cultures in developing countries.

There are numerous studies on entrepreneurial intention among universities, college and institution students as sampling objects (Krueger, 1993; Krueger \& Brazeal, 1994; Ismail et al., 2009; Chuah et al., 2016, Barba-Sánchez \& Atienza-Sahuquillo, 2018). It is important to examine the cognitive process related to entrepreneurial intention and determine clear awareness of orientation of entrepreneurship to explain the reasons why individuals setting up business, especially students at universities and colleges, who have been training officially, might become the potential entrepreneurs in the future.

\subsection{Entrepreneurial migration}

Entrepreneurship and migration problems are considered at the very top of many countries in the world (Naudé et al., 2015). There are many reasons explain why: First, in terms of worldwide self-employment, a billion entrepreneurs and over 232 million cross-border migrants are probably measured (United Nations, 2013). Secondly, both migrants and entrepreneurs might not only have substantial effects on the development of the country but it also invests billions into the economy and create jobs. According to World Bank (2013), for example, the estimation of migrant remittances reached at approximately 550 billion per year. Finally, the contribution of migrants and entrepreneurs to the poverty reduction is recorded in many countries (Adams \& Page, 2005). As a result, Naudé et al. (2015) emphasized that many policy makers, NGOs, donors and others have taken attention into both migration and entrepreneurship, especially transnational entrepreneurship, because of their possible influences on economic development and poverty reduction. 
Entrepreneurial migration research has attracted attention of many scholars, who realized that instead of finding a job, a particular kind of migrants, who have similar characteristics to entrepreneurs, create a new venture for themselves in the locals. The growing number of migrants in developing countries come to developed ones to run a business and create jobs for the natives (Ndoan et al., 1998). That migrants involved in entrepreneurial activities have been found in almost all researches of ethnic entrepreneurs (Kobrin \& Speare, 1983; Lewandowski, 1980; Lin et al., 2017). It is noticeable that there are different characteristics among entrepreneurial migration and labor migration. Indeed, labor migrants are interested in the availability of job opportunities, competitive level of labor market and salary in the host country and they also attract more attention to technical skills in their works, while entrepreneurial migrants attend more to find the best place to invest and increase the profits, they not only search the successful opportunities but also generate jobs for the native people. Furthermore, they also concern on leadership abilities, management skills, and the establishment of business relationship in the local market. This paper also explores the migration attitudes of Vietnamese and Polish students, who intent to set up their own business.

\subsection{An overview of Vietnamese and Polish entrepreneurship}

This section presents an overview of entrepreneurship situation in Vietnam and Poland. A brief economic background of each country is introduced in the Table 1. In terms of World Economic Forum Global Competitiveness, although Vietnam and Poland are rather similarly rated (4.3 and 4.6), the former was much higher in the rank, at 63/138 and 36/138 respectively. This result shows that despite Vietnam could boost its competitiveness and close gaps in the global ranking, it is still so far from Poland. In addition, the similar rank is witnessed in the category of starting a business (121/190 and 107/190), but Poland was seen as much easier than Vietnam to do business. Noticeably, SMEs only contributed to 40\% GDP in Vietnam, while this proportion in Poland was 52\%.

\section{Table 1}

Economic indicators for Vietnam and Poland

\begin{tabular}{lll}
\hline Indicators & Vietnam & Poland \\
\hline Population & 91.7 million*** & 38.0 million*** \\
GDP & $\$ 191.5$ billion** & $\$ 474.9$ billion** \\
GDP per capita & $\$ 1,980^{* * *}$ & $\$ 13,370^{* * *}$ \\
SME contribution to GDP & $40 \% *$ & $52 \% * *$ \\
World Bank Ease of Doing Business Rank & $82 / 190^{* * *}$ & $24 / 190^{* * *}$ \\
World Bank Starting a business Rank & $121 / 190^{* * *}$ & $107 / 190^{* * *}$ \\
World Economic Forum Global Competitiveness Rating & $4.3 / 7$ (Rank: 63/138)*** & $4.6 / 7($ Rank: $36 / 138) * *$ \\
Economic Development Phase & Efficiency-Driven & Efficiency-Driven \\
\hline
\end{tabular}

*2013 Figures, **2015 Figures, ***2017 Figures

Sources: Singer et al., 2018, p. 85, 101.

Entrepreneurial sector is really dynamic in Poland, especially when it comes to starting a small business. According to GEM Report in Poland (2017), approximately 21\% of Polish adults aged from 18 to 64 years plan to set up or run a business within the next three years. This rate is the $5^{\text {th }}$ highest in the European Union, where only $12 \%$ of the residents consider starting their own business within the next three years.

Table 2

Key entrepreneurial indicators for Vietnam and Poland

\begin{tabular}{|c|c|c|c|c|}
\hline \multirow[t]{2}{*}{ Indicators } & \multicolumn{2}{|c|}{ Vietnam } & \multicolumn{2}{|c|}{ Poland } \\
\hline & Value $(\%)$ & Rank/54 & Value $(\%)$ & Rank/54 \\
\hline Entrepreneurial Spirit Index & 0.26 & $15 \mathrm{~T}$ & 0.42 & 4 \\
\hline Perceived opportunity & 46.4 & $23 \mathrm{~T}$ & 68.8 & 3 \\
\hline Perceived capacities & 53.0 & 19 & 52.4 & 20 \\
\hline Fear of failure & 46.6 & 10 & 34.4 & $30 \mathrm{~T}$ \\
\hline Entrepreneurial intentions & 25.0 & 19 & 9.7 & 44 \\
\hline Total Early-Stage Entrepreneurial Activity (TEA) 2017 & 23.3 & $6 / 54$ & 8.9 & $34 \mathrm{~T} / 55$ \\
\hline Total Early-Stage Entrepreneurial Activity (TEA) 2016 & N/A & N/A & 10.7 & $30 / 65$ \\
\hline Total Early-Stage Entrepreneurial Activity (TEA) 2015 & 13.7 & $20 \mathrm{~T}$ & 9.2 & $38 \mathrm{~T} / 60$ \\
\hline Established business ownership rate (EBO) & 24.7 & $3 / 54$ & 9.8 & $10 / 54$ \\
\hline Entrepreneurial Employee Activity-EEA & 0.6 & $45 \mathrm{~T} / 54$ & 3.2 & $22 / 55$ \\
\hline Improvement-Driven Opportunity/Necessity Motive & 4.6 & 9 & 7.5 & 4 \\
\hline Female/Male TEA Ration & 1.14 & 1 & 0.78 & $18 \mathrm{~T}$ \\
\hline Female/Male Opportunity Ratio & 0.94 & $27 \mathrm{~T}$ & 1.01 & $14 \mathrm{~T}$ \\
\hline Job expectation & 9.1 & 44 & 14.9 & 34 \\
\hline Innovation & 13.9 & $48 \mathrm{~T}$ & 12.1 & 51 \\
\hline Industry (\% in Business Service Sector) & 6.5 & 43 & 17.1 & 28 \\
\hline High status to entrepreneur & 74.8 & 15 & 67.7 & 31 \\
\hline Entrepreneurship a good career choice & 62.1 & 27 & 79.3 & 5 \\
\hline
\end{tabular}

Also, Poland is currently ahead of innovation-driven economies in the European Union, reaching at $15 \%$, compared with $26 \%$ and 30\% among factor-driven and efficiency-driven economies respectively. In addition, a new Index of Entrepreneurial Spirit has been presented in the Global Report for 2017/18. This index is very useful for policy makers when it is possible to compare countries within entrepreneurial framework conditions. The Entrepreneurial Spirit Index in Poland valued 0.42 (rank: $4 / 54$ 
countries), which was much higher than Vietnam, with only 0.26 (rank: 15T/54). In terms of entrepreneurial intention, perceived opportunities and entrepreneurial skills and knowledge are seen as the decisive factors to start up a business. In Poland, the proportion of adults perceived opportunities to create an own business in their environment is extremely high, at $68.8 \%$ (the $3^{\text {rd }}$ highest in the rank), followed by $52.4 \%$ Polish adults who believe their skills and knowledge sufficient to set up a business, and only $34.4 \%$ people who fear failure. However, although the percentage of Vietnamese adults who consider their skills and knowledge enough to run a business is similar to Polish adults (53\%), the figure for adults perceived opportunities is just $46.4 \%$, and fears of failure is rather high, at $46.6 \%$. Total Early-stage Entrepreneurial Activity (TEA indicator) refers to new entrepreneurial activities (less than 3.5 years) and just started up business (less than 3 months), which has been developed by GEM study in order to evaluate the situation of entrepreneurship development of countries. TEA 2017 in Vietnam reached 23.3\% (rank: 6/54), which was nearly fourfold higher than TEA in Poland (only 8.9\%).

Apart from individual entrepreneurship, GEM report also attracts attention to organization entrepreneurship (intrapreneurship). It means that an employee starts up his/ her own business. The EEA indicator is measured in order to provide the information of this form of entrepreneurship. Table 2 reports that EEA in Vietnam only is accounted for $0.6 \%$ (45/54 countries), whereas this indicator in Poland made up for 3.2\% (22/55 countries). These results illustrate that the percentage of entrepreneurial activities among employees in companies, organizations in Vietnam is fivefold lower than that of those in Poland. The motivation driving people who want to become an entrepreneur is seen as the key elements to know the essence and quality of entrepreneurship in a country. On behalf of individuals who are currently owner-manager of an established business and have been for more than 42 months, the Vietnamese EBO rate was above twofold higher than that in Poland. The indicator of improvement driven opportunity (young entrepreneurs, who are motived by the hope to take advantage of the business opportunity throughout improving personal income, obtaining working time flexibility and independence) in Vietnam was 4.6 and stood for the $9^{\text {th }}$ in the 54 countries, compared to 7.5 in Poland (4/54 countries).

Woman in both Vietnam and Poland increasingly have much potential for career development. The ration of women to men participating in entrepreneurship (Female/Male TEA Ration) and the ration of women to men who see good opportunities to start a business (Female/Male TEA Ration) in Vietnam were 1.14 (the highest rank in 54 countries) and 0.94 respectively, while these rations in Poland gained at 0.78 and 1.01. Finally, apart from the last indicators, authors would present the level of innovativeness of technologies in Vietnam and Poland. This indicator was introduced by GEM studies and it is measured by three principal questions involved in the application of modern technologies, the novelty level of offered products from the consumers' perspective, and the competitive level in the business market. Innovation indicators in both countries were really low, $13.9 \%$ in Vietnam and $12.1 \%$ in Poland. The results took Vietnam and Poland at the lowest rank in the research, $48 \mathrm{~T}$ and $51 / 54$ countries.

\section{Methodology}

As mentioned, both studies were conducted in the similar ways in order to compare results between Vietnam and Poland. The following section explains research tasks, research questions, as well as methods followed.

\subsection{Research tasks and research questions}

The fundamental objective of this study was to analyze entrepreneurial intention and migration attitudes among students in Vietnam and Poland. This research also determines the factors leading to Vietnamese and Polish students to start their own business. From the research objective, the authors would like to answer the following research questions:

1. Do university students in Vietnam and Poland consider to set up a new firm?

2. Do university students in Vietnam and Poland know what competences are required to set up the firm?

3. Do university students in Vietnam and Poland know realities of becoming entrepreneur?

4. Do university students in Vietnam and Poland want to migrate abroad after they graduate? Under what circumstances the Vietnamese and Polish university students decide to go to work abroad?

Concretely, this key research aims the following five research tasks, which could be formulated as follows:

- Comparative analysis of willingness to take the risks among Vietnamese and Polish students,

- Comparative analysis of current professional activities among Vietnamese and Polish students,

- Comparative analysis of awareness of how to set up a business, and understanding of competitors, target customers, financial resource management among Vietnamese and Polish students,

- Comparative analysis of what determinants led Vietnamese and Polish students to start their own business,

- Comparative analysis of how do Vietnamese and Polish students assess the skills and qualifications they acquired during their studying in preparation to run their own business,

- Comparative analysis of what circumstances motivate the Vietnamese and Polish university students to go to work abroad and the purpose of them in case of going abroad.

\subsection{Study area, sample and research method}


The population of the proposed study included Vietnam (located in Southeast Asia) and Poland (situated in Eastern Europe). While Poland is classified as an efficiency-driven economy, Vietnam has also reached its important turning point in the transitional stage of development from the "factor-driven economy" to the "efficient-driven economy" (Kabe et al., 2016, p.151). An efficiency-driven economy can be perceived as a country which produces more advanced production processes, increased service and product quality in an efficient manner. Such countries normally invest in infrastructure, business friendly government administration, required skills and good investment encouragements (Singer et al., 2018, p.13).

The following formula has been used to calculate a minimum size of research sample (Szajt, 2014, p.40):

$$
\mathrm{n}=\frac{u_{\propto}^{2}}{4 d^{2}}=\frac{1.64^{2}}{4 * 0.06^{2}}=187
$$

Approximately 900 questionnaires were distributed to university/ college students in each study area by utilizing Google Forms, a web-based form solution system, which allows researchers to design online surveys and questionnaires. Although there are 663 Vietnamese student answered surveys $\left(\mathrm{N}_{1}=663\right)$ and 710 Polish students responded surveys $\left(\mathrm{N}_{2}=710\right)$, but only 289 Vietnamese students $\left(\mathrm{N}^{\prime}{ }_{1}=289\right)$ and 333 Polish students $\left(\mathrm{N}^{\prime}{ }_{2}=333\right)$ would like become entrepreneurs. Based on the literature review and the research objectives, the survey was divided into four sections. In the first section, demographic questions are designed to obtain the better information of profile of respondents, which includes ages, genders, education, current professional activities, and the level of own willingness to take the risks. In the second section, the additional questions are designed to know the information of the assessment of students of involving high risks when running own business, the understanding of students of competitors, market, target customers, financial resources and assessment of them about the usefulness of studying at universities for preparing a plan to run a business. Then, in third section, the questions are used to determine factors leading the Vietnamese and the Polish students to start up their own businesses. Finally, the fourth section includes the questions related to migration attitudes of students. The authors used certain elements of descriptive statistics and Mann Whitney $U$-Test through SPSS 20.0 in order to analyze the differences between the entrepreneurial intention and migration attitudes in Vietnam and Poland. The following formula is implemented to calculate U-Statistic in Mann Whitney UTest (Berry et al., 2012).

$$
U=n_{1} n_{2}+\frac{n_{2}\left(n_{2}+1\right)}{2}-\sum_{i=n_{1}+1}^{n_{2}} R_{i}
$$

where $\mathrm{R}_{\mathrm{i}}=$ sum of ranks for scores, $0 \leq \mathrm{U} \leq n_{1} n_{2}$

\section{Results}

Fig. 1 introduces a brief demographic layout of respondents and the possibility of starting a business in Vietnam and Poland. With the participant of 663 Vietnamese and 710 Polish to answer questionnaires, authors would show that the proportion of male and female carried out our research are similar to Vietnam and Poland (34.5\% and 65.5\% in Vietnam, 35.1\% and 64.9\% in Poland respectively).

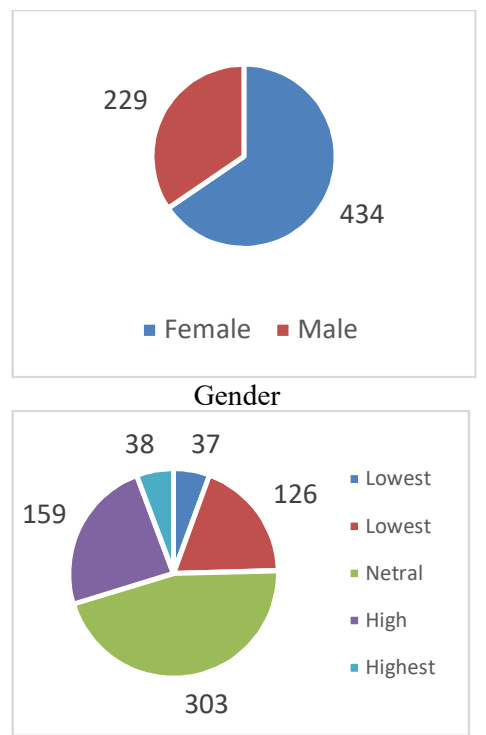

Rate willingness to take risks

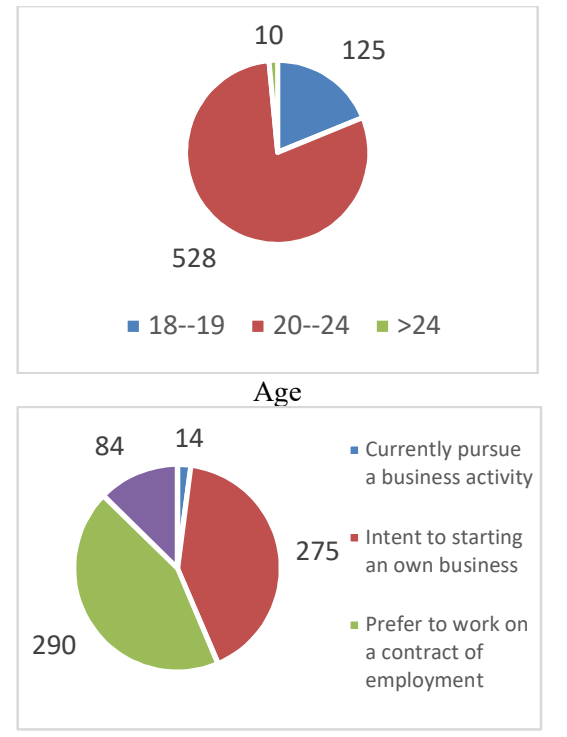

Possibility of starting an own business

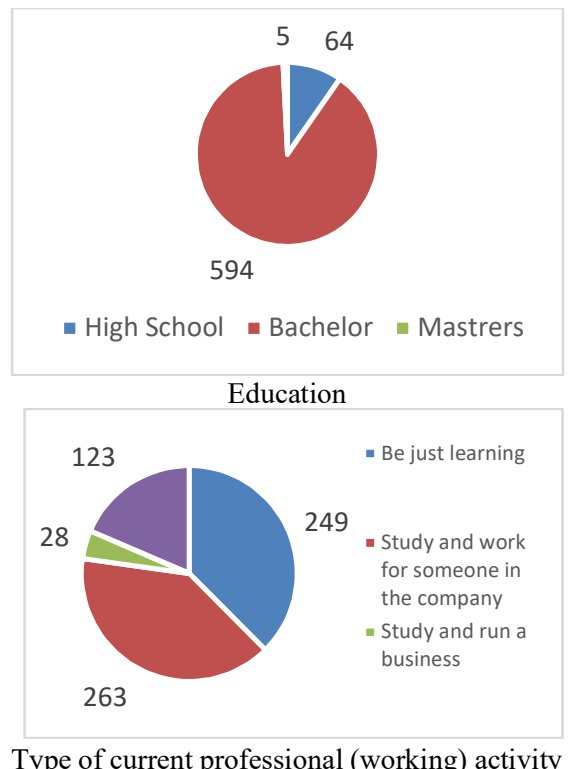

Type of current professional (working) activity

Fig. 1. Demographical information and some other information related to entrepreneurial intention of samples Note: $\mathrm{N}_{1}=663, \mathrm{~N}_{2}=710$, F: Frequency 
Almost all Vietnam and Polish respondents are between 20 and 24 years old, $79.6 \%$ in Vietnam and $77 \%$ in Poland. This result also proves that the majority of them are undergraduate students (bachelor), reaching $89.6 \%$ in Vietnam and $64.2 \%$ in Poland. However, $32.1 \%$ of Polish respondents are graduate students (master), while the figure for Vietnam is only $0.8 \%$. In terms of willingness to take risks in business, nearly half of Vietnamese and Polish students rated at neutral level, $45.7 \%$ and $41.8 \%$ respectively, but the proportion of willingness to take risks at the high and highest level in Poland (40\%) is greater than in Vietnam (29.1\%). In addition, while a big portion of Polish students are studying and looking for work, accounting for $68.2 \%$, this figure for Vietnamese students is just $18.6 \%$. In Vietnam, the proportion of students who are only learning is rather high, making up $37.6 \%$, but it is only $0.3 \%$ in Poland. The figure for students who are studying and running a business in two countries are rather small $\left(4.2 \%\right.$ in Vietnam and $1.8 \%$ in Poland). Although 663 Vietnamese students $\left(\mathrm{N}_{1}=663\right)$ and 710 Polish students $\left(\mathrm{N}_{2}=710\right)$ answered questionnaire surveys, but only 289 Vietnamese students $\left(\mathrm{N}^{\prime}{ }_{1}=289\right)$ and 333 Polish students $\left(\mathrm{N}_{2}{ }_{2}=333\right)$ would become entrepreneurs, reaching $43.6 \%$ and $46.9 \%$ respectively. 374 Vietnamese respondents and 377 Polish respondents either prefer to work on contract of employment or are no self/employment. Besides, examinations also were conducted in order to determine, according the respondents, their knowledge, skills and some information related to entrepreneurship.

Table 3

Student's answers involved in entrepreneurship in Vietnam and Poland

\begin{tabular}{|c|c|c|c|c|c|}
\hline \multirow[t]{2}{*}{ Items } & \multirow[t]{2}{*}{ Categories } & \multicolumn{2}{|c|}{ Vietnam } & \multicolumn{2}{|c|}{ Poland } \\
\hline & & $\mathrm{F}$ & $\%$ & $\mathrm{~F}$ & $\%$ \\
\hline \multirow[t]{2}{*}{ Consider that setting up an own business involves in high risks } & Yes & 210 & 72.7 & 279 & 83.8 \\
\hline & No & 79 & 27.3 & 54 & 16.2 \\
\hline \multirow[t]{2}{*}{ Know how to set up an own business } & Yes & 163 & 56.4 & 198 & 59.5 \\
\hline & No & 126 & 43.6 & 135 & 40.5 \\
\hline \multirow[t]{2}{*}{ Know who is competing with in the market } & Yes & 202 & 69.9 & 257 & 77.2 \\
\hline & No & 87 & 30.1 & 76 & 22.8 \\
\hline \multirow[t]{2}{*}{ Know who is the target customer } & Yes & 223 & 77.2 & 263 & 79.0 \\
\hline & No & 66 & 22.8 & 70 & 21.0 \\
\hline \multirow[t]{2}{*}{ Know the market where the company will be operating } & Yes & 181 & 62.6 & 187 & 56.2 \\
\hline & No & 108 & 37.4 & 146 & 43.8 \\
\hline \multirow[t]{2}{*}{ Own assets and financial resources needed to start the business } & Yes & 197 & 68.2 & 98 & 29.4 \\
\hline & No & 92 & 31.8 & 235 & 70.6 \\
\hline \multirow[t]{2}{*}{ Know how to organize financial resources to start a business } & Yes & 152 & 52.6 & 241 & 72.4 \\
\hline & No & 137 & 47.4 & 92 & 27.6 \\
\hline \multirow{5}{*}{$\begin{array}{l}\text { Assess the skills and qualifications acquired during studies to prepare for run- } \\
\text { ning own business }\end{array}$} & Diploma and necessary & 99 & 34.3 & 76 & 22.8 \\
\hline & Only diploma & 60 & 20.8 & 55 & 16.5 \\
\hline & Not useful & 38 & 13.1 & 19 & 5.7 \\
\hline & Difficult to say & 55 & 19.0 & 169 & 50.8 \\
\hline & Do not know & 37 & 12.8 & 14 & 4.2 \\
\hline
\end{tabular}

Note: $\mathrm{N}_{1}=289, \mathrm{~N}_{2}=333, \mathrm{~F}$ : Frequency

Source: Authors' elaborations based on research study

Table 3 indicates that students' answers involved in necessary knowledge and skills in an attempt to run a business are relatively similar in Vietnam and Poland. Particularly, whereas $72.7 \%$ Vietnamese students and $83.8 \%$ Polish students consider that setting up a business involves in high risks, the quantity of students who know how to set up a business is $56.4 \%$ in Vietnam and 59.5\% in Poland. In the matter of being aware of the competitors in the market, the target customers, the market where they intent to operate, how to organize financial resources effectively, the percentage of Vietnamese and Polish students who said "yes" are also rather similar, representing for $69.9 \%, 77.2 \%, 62.6 \%, 52.6 \%$ in Vietnam and $77.2 \%, 79.0 \%, 56.2 \%$, $72.4 \%$ in Poland. However, while the number of Vietnamese students who own assets and financial resources needed to start a business made up $68.2 \%$, this proportion in Poland only reached $29.4 \%$. Noticeably, $22.2 \%$ Polish students believe that they go to university only to earn diploma and the knowledge, skills and qualifications required during studies are not useful, this figure was lower than in Vietnam, at 33.9\%. Nevertheless, more than half of Polish argued that it is difficult to say that the skills and qualification gained through studying was useful or not to prepare for running a business because they were studying, but $34.3 \%$ of Vietnamese students believe that going university would provide the knowledge, skills and diploma necessarily to run a business.

In Table 4, The Mann-Whitney U-Test is employed to compare whether there are differences in the variables for two independent samples (Vietnam and Poland). With the level of significant $\alpha=0.05$, The Mann-Whitney U-Test shows that in terms of analyzing 17 factors ( 17 variables) related to the entrepreneurial intention, only 5 factors (1-willingness to prove own value, 2-experience, 5-example of family and friends, 14-higher prestige of the workplace, and 17-easy to set up business and transparent law rules) influenced on entrepreneurial intention similarly. There are differences in affecting on entrepreneurial intention by 12 last factors (P-value $<0.05$ ) including 3- Inborn resourcefulness, 4-The pursuit of self-reliance, 6- A need of getting fair (decent) income, 7-Lack of work, 8-Necessity to acquire funds for living, 9-Employer requirement, 10- Higher earnings, 11-Greater possibility of self-realisation and job satisfaction, 12-Flexible working hours, 13- Greater responsibility, 15, Ability to improve your own qualifications, 16-Confidence in employment. 
Table 4

Factors affecting on entrepreneurial intention in Vietnam and Poland

\begin{tabular}{|c|c|c|c|c|c|c|c|c|c|c|c|c|c|c|}
\hline \multirow[t]{3}{*}{ Factors } & \multicolumn{5}{|c|}{ Vietnam } & \multicolumn{7}{|c|}{ Poland } & \multirow{2}{*}{\multicolumn{2}{|c|}{$\begin{array}{l}\text { Mann-Whitney } \\
\text { U-Test }\end{array}$}} \\
\hline & & & & & & & & & & $\mathrm{F}$ & & & & \\
\hline & 0 & 1 & 2 & 3 & 4 & 5 & 0 & 1 & 2 & 3 & 4 & 5 & Z & $\begin{array}{l}\text { P- } \\
\text { Value }\end{array}$ \\
\hline 1. Willingness to prove your own value & 27 & 16 & 49 & 71 & 100 & 26 & 19 & 27 & 46 & 92 & 90 & 59 & 1.550 & 0.121 \\
\hline 3. Inborn resourcefulness & 17 & 25 & 64 & 92 & 79 & 12 & 8 & 17 & 48 & 99 & 101 & 60 & 5.549 & $0.000^{*}$ \\
\hline 4.The pursuit of self-reliance & 12 & 15 & 33 & 86 & 105 & 38 & 1 & 6 & 22 & 56 & 128 & 120 & 7.720 & $0.000^{*}$ \\
\hline 5.Example of family, friends & 24 & 30 & 80 & 79 & 65 & 11 & 23 & 42 & 75 & 80 & 65 & 48 & 1.898 & 0.058 \\
\hline 6.A need of getting fair (decent) income & 8 & 16 & 44 & 95 & 93 & 33 & 4 & 6 & 14 & 59 & 119 & 131 & 9.284 & $0.000 *$ \\
\hline 8.Necessity to acquire funds for living & 13 & 22 & 45 & 105 & 86 & 18 & 38 & 48 & 64 & 98 & 84 & 332 & 4.701 & $0.000 *$ \\
\hline 9.Employer requirement & 23 & 26 & 64 & 82 & 79 & 15 & 82 & 60 & 87 & 61 & 24 & 19 & -7.928 & $0.000 *$ \\
\hline 10.Higher earnings & 5 & 14 & 39 & 79 & 113 & 39 & 3 & 11 & 13 & 49 & 132 & 161 & 7.753 & $0.000^{*}$ \\
\hline 11.Greater possibility of self-realisation and job satisfaction & 10 & 8 & 33 & 74 & 122 & 42 & 2 & 2 & 10 & 35 & 123 & 118 & & $0.000^{*}$ \\
\hline 12.Flexible working hours & 7 & 15 & 31 & 73 & 117 & 45 & 3 & 12 & 40 & 62 & 98 & 42 & 4.045 & $0.000 *$ \\
\hline 13.Greater responsibility & 6 & 11 & 32 & 86 & 103 & 51 & 9 & 21 & 57 & 117 & 87 & 82 & -3.755 & $0.000^{*}$ \\
\hline 14.Higher prestige of the workplace & 6 & 15 & 29 & 87 & 99 & 53 & 8 & 19 & 33 & 87 & 104 & 129 & 1.041 & 0.298 \\
\hline 15.Ability to improve your own qualifications & 7 & 11 & 29 & 70 & 108 & 64 & 5 & 5 & 23 & 51 & 120 & 121 & 4.909 & $0.000^{*}$ \\
\hline 16.Confidence in employment & 8 & 12 & 32 & 76 & 98 & 63 & 8 & 13 & 35 & 43 & 113 & 68 & 3.766 & $0.000^{*}$ \\
\hline
\end{tabular}

If I had better career prospects there than in my home country

If I had the same rights as the citizens of the country to which the trip would be planned

Only if I could go abroad with my family

I could have learned a foreign language better

Abroad I would earn more money

I do not see another possibility to earn money

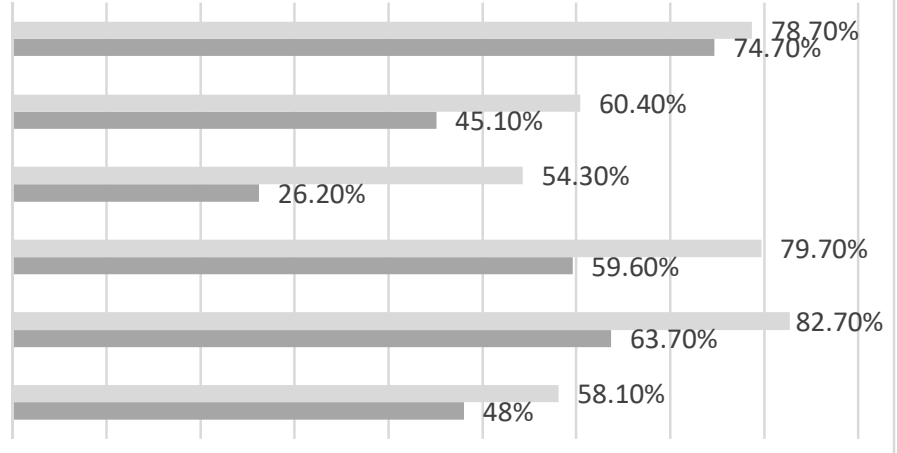

$\sim$ Poland $\quad$ Vietnam

Note: $\mathrm{N}_{1}=663, \mathrm{~N}_{2}=710$

Fig. 2. The circumstances lead Vietnamese and Polish students decide to go to work abroad

Source: Authors' elaborations based on research study

In terms of what motivates Vietnamese and Polish students decide to go to work abroad, overall, the percetage of respondents agreed on statements in Poland is much higher than that of those in Vietnam. Specifically, 78.7\% of the Polish students might go abroad if they have better career prospects there than their home country, compared with $74.7 \%$ of the Vietnamese students who argreed on this statement. The proportion of Polish students would plan to come a country where they have the same rights as the citizens make up $60.4 \%$, which is approximetely $15 \%$ higher than that of those in Vietnam. However, $54.3 \%$ Polish students would go abroad with their families, and this figure in Vietnam is only $26.2 \%$, which means that $74.8 \%$ of Vietnamese students are ready to go abroad to work alone. In addition, 79.7\% of Polish students believe that they are likely to learn a foreign language well, and $82.7 \%$ of them consider that they can earn more money when go abroad. These figures in Vietnam are just $59.6 \%$ and $63.7 \%$ respectively.

Fig. 3 shows the purpose of Vietnamese and Polish respondents when they go abroad. Overall, the popular tendency in two countries towards going abroad is to find a job (both incidental and long-term job). Particularly, $88.4 \%$ of the Polish students would like travelling abroad to find a job ( $51.5 \%$ for long period and $36.9 \%$ for incidental work), compared with $80.7 \%$ among Vietnamse students (43.9\% for long period and $36.8 \%$ for incidental work). Only $8.4 \%$ of the Vietnamese students would go aboard to start up a business, which is higher than Polish students (only 6.5\%). Interestingly, the percentage of Vietnamese and Polish students plan to extent their existing business activities are 5.9\% and $2.0 \%$ respectively. Beside, 5\% Vietnamese students would work in grey economy when they go abroad, while this figure for Polish students is only $3.1 \%$. 


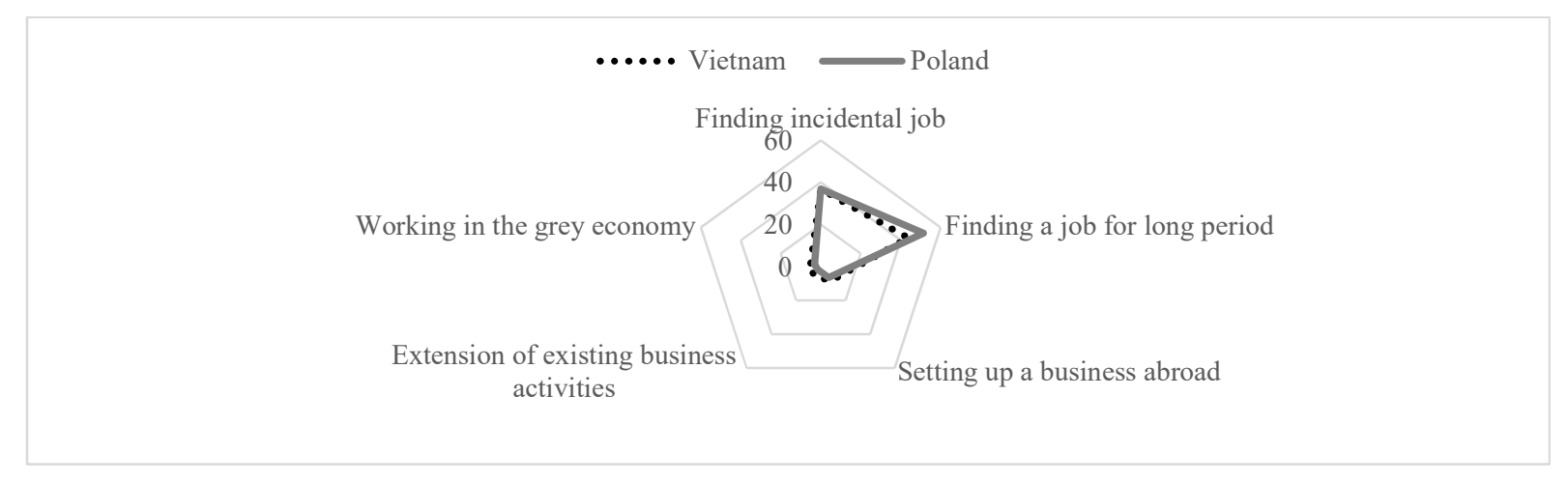

Note: $\mathrm{N}_{1}=663, \mathrm{~N}_{2}=710$

Fig. 3. The purpose of Vietnamese and Polish respondents in case of going abroad

\section{Conclusion}

Entrepreneurship and migration become one of the emerging issues in such countries as Vietnam and Poland and in the rest of the world because of substantial influences on the development of each country' economy. Our study provides more additional understandings of entrepreneurial intention and migration attitudes. By comparing two developing countries, authors have shown the differences in terms of factors affecting on entrepreneurial intention and awareness of skills and knowledge among Vietnamese and Polish towards entrepreneurship fields as well. Research results have indicated that despite there are rather similar in demographic layout related to gender, age group and education of participants, there are many differences in the level of willingness to take risks, knowledge and skills involved in how to run a business, how to use financial resources efficiently, and student' understanding of competitors, target customers, and the market. In addition, the results also show that there are differences in 12 out of 17 factors affecting the intention to start up a business between the Vietnamese and the Polish students, and only, 5 of 17 factors have similar effects on entrepreneurial intention. In terms of migration attitudes, the majority of respondents in two countries would go abroad if they find the career prospects in their host countries. However, more than $80 \%$ respondents in Vietnam and Poland would like going abroad to find a job instead of running own business. Although our study provides a new viewpoint of entrepreneurship field and migration, authors only compared the differences in factors effecting on entrepreneurial intention and migration attitudes among students in two transitional economies (Vietnam and Poland), authors still do not indicate the tendency and level of these effects (positive or negative effects). This limitation is seen as a gap research for further studies.

\section{References}

Adams, Jr, R. H., \& Page, J. (2005). Do international migration and remittances reduce poverty in developing countries?. World development, 33(10), 1645-1669.

Ajzen, I. (1991). The theory of planned behavior. Organizational behavior and human decision processes, 50(2), 179-211.

Ambrish, D. R. (2014). Entrepreneurship development: An approach to economic empowerment of women. International Journal of Multidisciplinary Approach and Studies, 1(6), 224-232.

Bernat, T., Maciejewska-Skrendo, A., \& Sawczuk, M. (2016). Entrepreneurship-Risk-Genes, experimental study. Part 1-entrepreneurship and risk relation. Journal of International Studies, 9(3), 270-278.

Berry, K. J., Mielke Jr, P. W., \& Johnston, J. E. (2012). The two-sample rank-sum test: Early development. Electronic Journal for History of Probability and Statistics, 8, 1-26.

Barba-Sánchez, V., \& Atienza-Sahuquillo, C. (2018). Entrepreneurial intention among engineering students: The role of entrepreneurship education. European Research on Management and Business Economics, 24(1), 53-61.

Bird, B. (1988). Implementing entrepreneurial ideas: The case for intention. Academy of management Review, 13(3), 442-453.

Bird, B., \& Brush, C. (2002). A gendered perspective on organizational creation. Entrepreneurship theory and practice, 26(3), 41-65.

Churchill, N., \& Bygrave, W. D. (1989). The Entrepreneur ship Paradigm (I): A Philosophical Look at Its Research Methodologies. Entrepreneurship Theory and practice, 14(1), 7-26.

Chuah, F., Ting, H., Run, E. C., \& Cheah, J. H. (2016). Reconsidering what entrepreneurial intention implies: The evidence from Malaysian University students. International Journal of Business and Social Science, 7(9), 85-98.

De Bruin, A., Brush, C. G., \& Welter, F. (2007). Advancing a framework for coherent research on women's entrepreneurship. Entrepreneurship Theory and Practice, 31(3), 323-339.

Do, B. R., \& Dadvari, A. (2017). The influence of the dark triad on the relationship between entrepreneurial attitude orientation and entrepreneurial intention: A study among students in Taiwan University. Asia Pacific Management Review, 22(4), 185-191.

Doing Business in Vietnam (2017), A reference guide for entering the Vietnam market, https://www.pwc.com/vn/en/publications/2017/dbg2017.pdf (10.02.2018).

Esfandiar, K., Sharifi-Tehrani, M., Pratt, S., \& Altinay, L. (2019). Understanding entrepreneurial intentions: A developed integrated structural model approach. Journal of Business Research, 94, 172-182.

Fishbein, M.\& Ajzen, I. (1975) Belief, Attitude, Intention, and Behavior: An Introduction to Theory and Research, Addison-Wesley, New York. 
Gawel, A. (2010). The relationship between entrepreneurship and unemployment in the business cycle. Journal of International Studies, 3(1), 59-69.

Gartner, W. B., Bird, B. J., \& Starr, J. A. (1992). Acting as if: Differentiating entrepreneurial from organizational behavior. Entrepreneurship theory and practice, 16(3), 13-32.

GSO (2017), Social and Economic Situation in 2017, https://www.gso.gov.vn/default en.aspx?tabid=622\&ItemID=18670 (20.02.2018).

Ismail, M., Khalid, S. A., Othman, M., Jusoff, H. K., Rahman, N. A., Kassim, K. M., \& Zain, R. S. (2009). Entrepreneurial intention among Malaysian undergraduates. International Journal of Business and Management, 4(10), 54-60.

Kot, S., Meyer, N., \& Broniszewska, A. (2016). A cross-country comparison of the characteristics of Polish and South African woman entrepreneurs, 2, 19-28.

Kabe, S., Ushiyama, R. Kinkyo, T. \& Hamori, S. (2016) Moving up the ladder-development challenges for low and middle-income Asia, World Scientific Publishing, Singapore.

Kirzner, I. (1985). Discovery and the capitalist process. Chicago: University of Chicago Press.

Kobrin, F. E., \& Speare Jr, A. (1983). Out-migration and ethnic communities. International Migration Review, 17(3), 425-444.

Kopycińska, D., Bernat T., \& Korpysa, J. (2006), Researching student's entrepreneurship skills in post-socialist countries: A multi-country survey, Transformation in Business \& Economics, 8(3).

Korpysa, J. (2012), Entrepreneurial attitudes adopted by employees of Polish enterprises undergoing restricting. Transformation in Business \& Economics, 11, 456-477.

Kot, S., Meyer, N., \& Broniszewska, A. (2006). A cross-country comparison of the characteristics of Polish and South Africa women entrepreneurs. Economics and Sociology, 9(4), 207-221.

Krueger, N. (1993), The impact of prior entrepreneurial exposure on perceptions of new venture feasibility and desirability, Entrepreneurship: Theory and Practice, 18(1), 5-22.

Krueger, N. F., \& Brazeal, D. V. (1994). Entrepreneurial potential and potential entrepreneurs. Entrepreneurship: Theory and Practice, 18, 91.

Krueger, N. F., Reilly, M. D., \& Carsrud, A. L. (2000). Competing models of entrepreneurial intentions. Journal of Business Venturing, 15(5), 411-432.

Krueger, N. (2008). Entrepreneurial Resilience: Real and Perceived Barriers to Implementing Entrepreneurial Intentions, Working Paper, SSRN 1155269.

Lee, L., Wong, P. K., Foo, M. D. \& Leung, A. (2011), Entrepreneurial intentions: The influence of organization and individual factors, Journal of Business Venturing, 26, 124-136.

Lewandowski, S. (1980). Migration and Ethnicity in Urban India: Kerala Migrants in the City of Madras, 1870-1970, New Delhi: Ramesh Jain Manohar Publications.

Lin, L. L., Peña, A. V., \& Chen, C. N. (2017). Factors related to the intention of starting a new business in El Salvador. Asia Pacific Management Review, 22(4), 212-222.

Naudé, W., Siegel, M. \& Marchand, K. (2015), Migration, Entrepreneurship and Development: A Critical Review, IZA Discuss Paper, No. 9284, 1-23.

Ndoan, L.M., Gorter, C., Nijkamp, P. \& Rietveld, P. (1998) Ethnic Entrepreneurship and Migration: A Survey from Developing Country, Tinbergen Institute Discussion Papers, No. 98-081/3, pp. 1-14, http://papers.tinbergen.nl/98081.pdf (12.04.2018).

Paul, J., \& Shrivatava, A. (2016). Do young managers in a developing country have stronger entrepreneurial intentions? Theory and debate. International Business Review, 25(6), 1197-1210.

Report on Global Entrepreneurship Monitor- Poland (2017), Polska Agencja Rozwoju Przedsiębiorczości, GEM, Warszawa.

Schumpeter, J. A. (1960), Teoria rozwoju gospodarczego, Warsaw: PWN.

Shane, S. \& Venkataraman. S. (2000). The promise of entrepreneurship as a field of research. Academy of Management Review, 25(1), pp. 217-226.

Singer, S., Herrington, M. \& Menipaz, E. (2018) 2017/18 Global Report, Massachusetts: Badson College.

Sivvam, M. (2012), Women entrepreneurship: An Indian perspectives, Saarbrücken, Germany: LAP Lambert.

Szajt, M. (2014), Przestrzeń w badaniach ekonomicznych, Częstochowa: Sekcja Wydawnictw Wydziału Zarządzania Politechniki Częstochowskiej.

Talpas, P. (2014). Integration of Romani women on the labor market. Polish Journal of Management Studies, 10(1), 198-203.

Thompson, E. R. (2009). Individual entrepreneurial intent: Construct clarification and development of an internationally reliable metric. Entrepreneurship Theory and Practice, 33(3), 669-694.

Timmons, J. A. (1985). New venture creation. Tata McGraw-Hill Education.

United Nations (2013). The number of international migrants worldwide reaches 232 million, Population Facts 2013/2. United Nations Department of Economic and Social Affairs, Population Division.

VNEXPRESS NEWS (2017) Vietnam receives highest-ever FDI inflow in 2017, https:/e.vnexpress.net/news/business/economy/vietnamreceives-highest-ever-fdi-inflow-in-2017-3688438.html (12.02.2018).

World Bank (2013). Migration and remittance flows: Recent trends and outlook, 20132016, Migration and Development Brief 21, The World Bank.

WORLD BANK (2017), Poland's GDP Growth to Reach 4\% in 2017, Before Slowing Down in 2018, Says World Bank, http://www.worldbank.org/en/news/press-release/2017/10/19/poland-gdp-growth-to-reach-4-2017-before-slowing-down-2018-saysworld-bank (20.02.2018)

Zimmerer, T. \& Scarborough, N. M. (1996), Entrepreneurship and new venture formation, New Jersey: Prentice Hall.

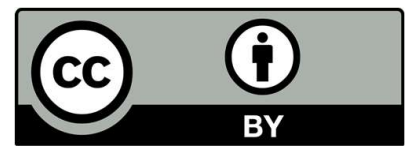

(C) 2020 by the authors; licensee Growing Science, Canada. This is an open access article distributed under the terms and conditions of the Creative Commons Attribution (CCBY) license (http://creativecommons.org/licenses/by/4.0/). 